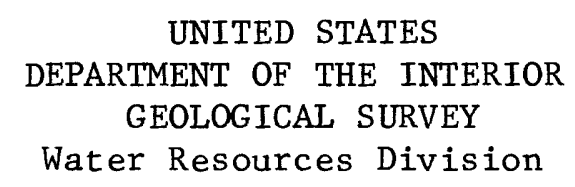

\title{
WATER-RESOURCES APPRAISAL OF CRATER LAKE NATIONAL PARK, OREGON
}

By F. J. Frank and A. B. Harris

Prepared in cooperation with

the National Park Service

Portland, Oregon

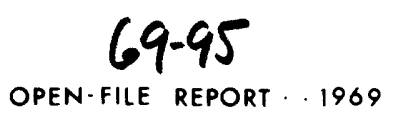


Abstract-1-1-

Introduction-

Geographic features-_. 2

Geologic features-a 5

General geology- 6

Relation of geology to occurrence of water- 6

Water supply- 7

Ground water-a. 7

Occurrence and availability- 7

Results of previous investigations-... 8

Streams and springs-... 8

Dependable flow- 13

Chemical quality-n 18

Utilization and development of water 18

Existing supplies-a 18

Potential at selected areas- 20

West Entrance-1. 20

North Entrance-1. 21

Old south boundary

South utility-. 23

North Junction-1. 24

Munson Valley-1 24

Potential at other areas- 24

Summary--

Selected references- 26 


\section{ILLUSTRATIONS}

Page

Figure 1. Map of Crater Lake National Park and adjacent areas---- 3

2. Map of the Crater Lake National Park area showing geology, stream- and spring-site numbers, and locations of test wells-... In pocket

3. Hydrograph showing comparison of flows of selected streams and springs with the concurrent flow of

Red Blanket Creek

4. Photograph showing Boundary Springs falls- 22

TABLES

Table 1. Average monthly temperature and precipitation at

Crater Lake National Park- 4

2. Lithologic $\log$ s of materials penetrated in test wells--- 9

3. Discharge measurements of streams and springs-15

4. Chemical analyses of water from streams and springs-.-. 19

A22 photographs in this report, except figure 4, are by the Oregon State Highway Department. 
WATER-RESOURCES APPRAISAL OF CRATER LAKE NATIONAL PARK, OREGON

By F. J. Frank and A. B. Harris

\section{ABSTRACT}

Crater Lake National Park is on the crest of the Cascade Range in southwestern Oregon. Except for small areas of glacial deposits, the area is underlain by volcanic rocks of Tertiary and Quaternary age. The principal rock types are andesitic and basaltic lavas, pumiceous volcanic flow breccias, tuffs, and airborne and flow pumice. The pumice is an excellent medium for the infiltration of much of the 67 inches of annual precipitation. The pumice and underlying lava flows and pyroclastic material transmit a large quantity of ground water which percolates to the water table and to various spring outlets.

In many areas of the park, the occurrence of perched ground water at altitudes below 6,500 feet is shown by numerous springs that drain water from ground-water bodies perched above the regional water table. Most of the streams and springs in the area flow throughout the year. The quality of the water is excellent. It is soft, has a low mineral content, and contains insignificant amounts of objectionable constituents.

During 1962, test drilling in the northern part of the park failed to locate perched-water bodies capable of supplying quantities of water adequate for proposed facilities. However, test drilling indicated that the regional water table is below an altitude of 4,960 feet and that wells at high altitudes may have to be drilled to depths exceeding a thousand feet to obtain water. Because the water table is at undetermined depth and the existence of productive perched ground-water bodies above the regional water table at a specific site cannot be predicted, the possibility of obtaining productive wells in the area is speculative. 
Springs that have proven to be adequate and dependable are the source of water supply for present facilities. The most favorable areas for the development of ground and surface water are in the western, southern, and southeastern parts of the park. These areas have a welldefined surface-drainage system and have many springs and streams at altitudes below 6,500 feet which discharge quantities of water adequate for additional park facilities.

\section{INTRODUCTION}

Crater Lake National Park is in a scenic mountainous area about 65 miles north of the Oregon-California State line, and its principal attraction is Crater Lake (fig. 1). The popularity and increased use of the park have placed increasing demands on existing camping facilities and have led to the consideration of additional sites for camping and other uses. Therefore, at the request of the National Park Service, the U.S. Geological Survey made a geologic and hydrologic appraisal of potential water supplies for new recreation sites.

This report explains the relation of the geologic environment to the occurrence of water. It also describes the hydrologic conditions, chemical quality of the water, and potential water supply of Crater Lake National Park.

Fieldwork was done during October 1967 and June and September 1968. Discharge measurements were made of streams and springs, water samples were collected and analyzed for chemical quality, and geologic reconnaissance was made of all major streams and springs.

Personnel of the Park Service, under the supervision of Donald $M$. Spalding, park superintendent, were helpful at all times and gave splendid cooperation, which is gratefully acknowledged. Particular thanks are given to Paul A. Larson, assistant park superintendent, and M. B. Evans, management assistant. The investigation was made under the general supervision of S. F. Kapustka, district chief in charge of water-resources investigations in Oregon, and under the immediate supervision of D. D. Harris, chief of the Hydrologic Investigations Section.

\section{GEOGRAPHIC FEATURES}

Crater Lake National Park is on the crest of the Cascade Range in southwestern Oregon. Altitudes range from 3,977 feet near Red Blanket Creek at the south park boundary to 8,926 feet atop Mount Scott. The park area is about 250 square miles, and its most prominent feature is Crater Lake, which occupies about 20 square miles. The lake occupies the crater of Mount Mazama, largest of several extinct volcanic cones that dot the park. The rim of the crater ranges in altitude from about 6,700 feet to more than 8,000 feet, and the lake level is about 6,170 feet. The area north of the lake is characterized by broad moderate slopes and flat areas broken by lava and cinder cones and several steep, rocky ridges. Steep-sided Mount Scott and rolling lava terrain with several steep-walled broad canyons are east of the lake. The area south 


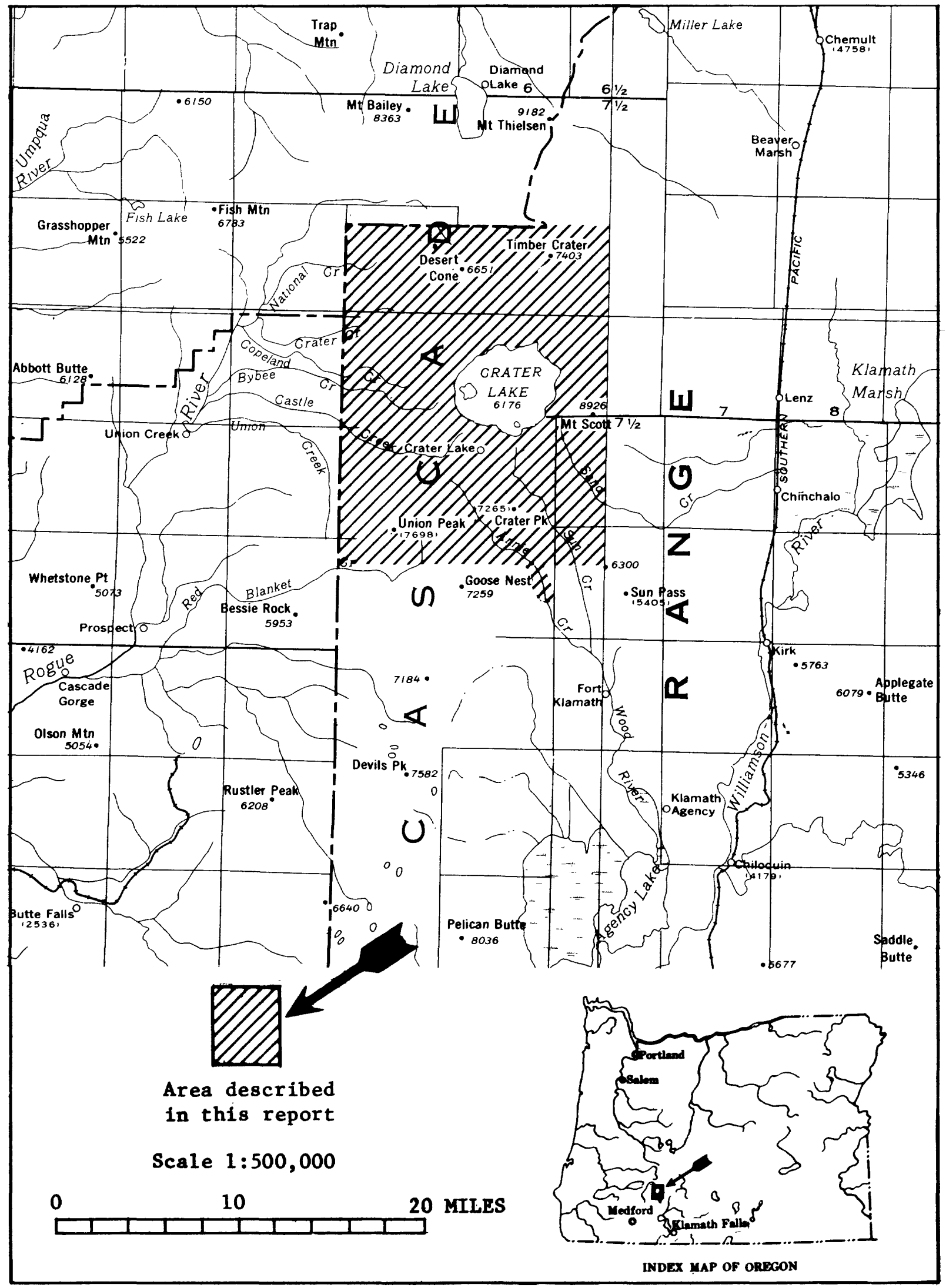

Figure 1.--Map of Crater Lake National Park and adjacent areas. 
Table 1.--Average monthly temperature and precipitation at Crater

\section{Lake National Park}

LFrom records of Environmental Science Services Adm., $1931-6 \underline{7} \bar{I} /$

\begin{tabular}{|c|c|c|}
\hline Month & $\begin{array}{l}\text { Temperature } \\
\left({ }^{\circ}\right)\end{array}$ & $\begin{array}{l}\text { Precipitation } \\
\quad \text { (inches) }\end{array}$ \\
\hline January & 25.4 & 11.05 \\
\hline February & 26.8 & 8.03 \\
\hline March & 28.0 & 8.29 \\
\hline April & 33.8 & 4.38 \\
\hline May & 40.3 & 2.98 \\
\hline June & 47.1 & 2.44 \\
\hline July & 55.5 & .75 \\
\hline August & 55.4 & .76 \\
\hline September & 49.8 & 2.04 \\
\hline October & 41.6 & 6.22 \\
\hline November & 33.2 & 8.24 \\
\hline December & 27.6 & 11.96 \\
\hline Average annual & 38.7 & 67.14 \\
\hline \multicolumn{3}{|c|}{$\begin{array}{l}\text { 1/ Published records not available for the years } 1942,1943 \text {, } \\
\text { 45, and 1946. Averages have been obtained from } 33 \text { years of }\end{array}$} \\
\hline
\end{tabular}


of the lake contains steep-walled broad valleys, intervalley ridges, and volcanic cones. West of the lake is a uniform, steep concave slope dissected by many small drainageways, some occupied by permanent streams.

The park is drained by tributaries of the Umpqua, Rogue, and Klamath River systems. The Rogue River and several of its tributaries head within the park.

The climate of Crater Lake National Park is cool and moist from October to May and cool and dry from June to September. From October to May, the precipitation, much of which is snowfall, is heavy. During much of the year, heavy snowfall restricts the full use of the park. Within the park boundaries, there are significant climatic differences. This is particularly true in the eastern part, where rainfall, snowfall, and temperature change significantly with changes in altitude.

Average monthly temperatures range from about $25^{\circ} \mathrm{F}$ in January to about $55^{\circ} \mathrm{F}$ in July. Annual precipitation at the U.S. Weather Bureau station at Crater Lake National Park headquarters averaged 67.14 inches during 1931-67 (table 1). This investigation covers the 1968 water year (October 1, 1967, to September 30, 1968), when precipitation was 52.35 inches--about 15 inches below average. Much of the precipitation falls as snow, and the area has an annual average snowfall of more than 575 inches. A complete study of the climatic conditions of the park was made by G. L. Sternes (1963). His report includes frequency tables of climatic conditions and tabulations of all monthly and seasonal values for the entire period of reliable record.

\section{GEOLOGIC FEATURES}

The broad platform of the Cascade Range is entirely of volcanic origin. It was built up layer upon layer by successive flows of lava and other volcanic material that issued from many vents. The total thickness of these materials amounts to several thousands of feet, as is readily apparent in the deeper valleys carved into the range by streams. The hollow circular-rimmed mountain that encloses Crater Lake is the remnant of Mount Mazama, a volcano of great altitude. Proof of the great altitude of the ancient peak is furnished by abundant evidence of the existence of large glaciers on its sides. The surface of the lava on its outer slopes show distinct scratches and grooves that could have been produced only by glaciers. Irregular piles of rock debris, called moraines, occur locally where they were left when the glaciers melted. Most significant of this glacial evidence are the valleys formed on the slopes of the mountain. The valleys have a U-shape and the smooth, parallel sides characteristic of glacial channels. During the final eruptions of Mount Mazama, much of the entire area of Crater Lake National Park was covered with pumice, scoria, and other pyroclastic materials. 


\section{General Geology}

With the exception of small areas of glacial deposits, Crater Lake National Park is underlain by volcanic rocks of Tertiary and Quaternary age. The geology of the area was studied by Diller and Patton (1902) and more extensively by Williams (1942). The distribution of the various volcanic units, modified after a map by Williams, is shown in figure 2 .

The principal rock types of the area are andesitic lava flows, basaltic lava flows, and pumiceous volcanic flow breccias and tuffs largely of dacitic and andesitic composition. The andesitic lava flows are the most common rocks in the park and are interstratified with flows of dacite and with glacial debris, as shown by the caldera walls of Mount Mazama.

The rock units as shown on figure 2 are (1) the pre-Mazama lavas, (2) lava flows, pyroclastic materials, and cinder cones, and (3) airborne and flow pumice. The pre-Mazama lavas consist of poorly permeable olivine and basaltic andesite and apparently lack much waterbearing capacity; therefore, they are not considered further as a source of water in this study. The lava flows, pyroclastic materials, and cinder cones consist of ejecta from ancestral Mount Mazama and are of andesitic, dacitic, and basaltic composition. Cinder cones which form Goose Nest, Red Cone, Timber Crater, and other Holocene volcanoes are mapped with this unit. The airborne and flow pumice consists of dacitic materials, including some semiconsolidated materials, and forms a mantle on the slopes and plains.

Irregular mounds of permeable glacial deposits exist in places at the base of the walls of Annie Creek and its middle fork, in the lower part of Sun Creek Canyon, and at the upper elevations of Sand and Wheeler Creeks. Because of their small areal exposure, the glacial deposits are not mapped on figure 2.

\section{Relation of Geology to Occurrence of Water}

The airborne and flow pumice is an excellent agent for the infiltration of precipitation. These volcanic rocks are highly permeable, and for that reason large areas of the park lack well-defined surfacedrainage systems. The northern part (fig. 2) has no permanent springs or streams above altitude 5,500 feet.

Together with the underlying lava flows, pyroclastic materials, and cinder cones, the pumice transmits large quantities of ground water that percolates to numerous spring outlets at various altitudes in the western, eastern, and southern parts of the park. Permeable beds in the volcanic rocks may vary in thickness and, in places, may have entirely eroded prior to the deposition of later lava flows. In other places, permeable beds of small areal extent may be intercalated with several lava flows of less permeable material. In any event, water 
moves rapidly downward through permeable beds to less permeable rocks, courses along the upper surfaces of the nearly impermeable material, and finally emerges as springs.

Small areas of glacial deposits, particularly in the southern part of the park, are permeable and transmit water by seeps and springs to streams. Locally, these deposits probably contain perched ground water; however, available data are insufficient to evaluate the deposits as sources of water supply.

Unlocated bodies of glacial deposits in other parts of the park may be concealed beneath thick blankets of pumice. If these deposits could be located and are saturated, they might supply usable quantities of water to wells.

\section{WATER SUPPLY}

\section{Ground Water}

With the exception of the two wells discussed below, there has been no development of ground water in the park through the use of wells. Although the source of spring discharge is from perched ground-water bodies, spring discharge is treated as surface water in this report.

\section{Occurrence and Availability}

At an undetermined depth below the surface of the park, all the rock pores are saturated, and the upper 1 imit of this saturation is known as the water table or the regional water table. Although the position of the regional water table is unknown in most places, it is perhaps no higher than Klamath Marsh (4,520 ft), about 15 miles east of the park headquarters. The altitude of the regional water table may vary from place to place, and at depth the regional water table.may slope in any direction. The main ground-water body may be compartmented by subsurface geologic structures. At certain places, zones of impermeable rock above the water table obstruct the downward percolation of water and cause saturation of some zones of porous rock. This ground water is called perched water. The occurrence of perched water in the park is shown by numerous springs that issue from the rocks above the regional water table. At many places, spring-fed streams seep into the permeable ground a short distance downslope from the springs, and the water percolates to the next lower perched zone or to the regional water table. The perched-water bodies are generally discontinuous, and the permeable zone in which they occur may be represented by impermeable materials a few feet away. This explains why one well may penetrate one or more perched-water zones whereas another well not far away may penetrate impermeable or non-water-bearing materials. 
In 1962, the National Park Service requested the Geological Survey to supervise drilling of two test wells--one well half a mile northwest of Cleetwood Cove and the other near the North Entrance to the park (fig. 2). Logs of the materials penetrated in the test wells are presented in table 2 .

The Cleetwood Cove test well was drilled 429 feet, to an altitude of about 6,220 feet--45 feet higher than the level of Crater Lake. Water entered the well at a rate estimated as less than 1 gpm (gallon per minute) and drained slowly through drill cuttings that filled the bottom 5 feet or more of the hole. No perched-water bodies capable of supplying water to a park facility were found in drilling this test hole.

The North Entrance well was drilled to a depth of 1,037 feet, or bottom-hole altitude of about 4,960 feet. At this depth, the bottom of the hole, which was dry, was about 220 feet below the 1 evel of Diamond Lake, 5 miles north, and about 1,220 feet below the level of Crater Lake, 6 miles south. This would indicate that these lakes are perchedwater bodies that 1 ie above the regional water table. A perched-water body was penetrated during the drilling of the North Entrance well. At a drilled depth of 296 feet the water level stood at a depth of 275 feet, and it was estimated that about half a gallon per minute was entering the hole. At a drilled depth of 340 feet the water stood at 297 feet. The well was bailed out to a depth of 340 feet and recovered 2 feet of water in 45 minutes. As in the Cleetwood Cove well, no perched-water bodies capable of yielding $5 \mathrm{gpm}$ were penetrated.

Results of the test drilling indicate that (1) in the northern part of the park perched-water bodies may be few or entirely lacking, (2) the altitude of the regional water table is below 4,960 feet near the North Entrance, and (3) wells drilled in the northern part and other areas of high altitude may have to be drilled to depths in excess of a thousand feet to obtain an adequate water supply.

\section{$\underline{\text { Streams and Springs }}$}

Throughout the park area, many streams and springs occur, some of which could provide adequate supplies of water to park facilities. The springs are at various altitudes, and most of them probably drain ground-water bodies perched above the regional water table. The larger springs form the headwaters of the streams that drain the park area; for example, Annie Springs, Anderson Spring, Cascade Spring, and Boundary Springs are the headwaters of Annie, Sand, and Bear Creeks, and Rogue River, respectively. Many spring-fed streams in the western and southern parts of the park are tributary to the major streams. 
Table 2.--Lithologic logs of materials penetrated in test wells

North Entrance test well

LSurface altitude about 6,000 ft $\bar{T}$

\begin{tabular}{lcc}
\hline Materials & $\begin{array}{c}\text { Thickness } \\
\text { (feet) }\end{array}$ & $\begin{array}{c}\text { Depth } \\
\text { (feet) }\end{array}$ \\
\hline
\end{tabular}

Pumice, reddish-brown, tan to pink; includes pebble-

sized particles of andesitic basalt_- 40

Cinders and pumice, dark-gray and reddish-brown,

grit-sized-1 55

Pumice, medium-gray, massive, contains scattered

basalt fragments up to 1/2-in. diameter-a 35

Glass, volcanic, gray, massive, shattered, and

pumice-1 87

Pumice, gray- 95

Andesite, medium-gray-_ 100

Glass, volcanic, gray- 105

Andesite, glassy, some basalt and pink pumice-_- $15 \quad 120$

Pumice, 1ight-tan, 1/8-in. to 1-in. diameter-a... 3123

Pumice, angular basalt fragments- 25

Andesite, gray, glassy (probably boulders)

Cinders, basaltic, reddish-brown, gray, black-_-_-- $18 \quad 145$

Pumice, gray- 50

Cinders or scoria, basaltic, dark-gray; cuttings

1/8-in. to 1/2-in. diameter-155

Lava, hard, medium-gray- $25 \quad 180$

Basalt, dark-gray, and reddish scoria-_ 55 
Table 2.--Lithologic logs of materials penetrated in test wells--

Continued

North Entrance test well--Continued

\begin{tabular}{ccc}
\hline Materials & $\begin{array}{c}\text { Thickness } \\
\text { (feet) }\end{array}$ & $\begin{array}{l}\text { Depth } \\
\text { (feet) }\end{array}$ \\
\hline
\end{tabular}

Basalt, medium-gray, fractured; cuttings up to 2 -in.

diameter 10

Basalt, dark-gray-_. 5

Scoria, basaltic, dark-gray-_... 5

Basalt, dark-gray, vesicular, grading to dense----- 20

Basalt, medium-gray, vesicular-_. 10

Cinders and scoria, red to black, basaltic-_.....- 25

Cinders and boulders of pumice, gray- 5

Andesite, gray, hard-_ 34

Cinders, black, some water... 2

Andesite, gray, hard-28

Andesite, dark-gray, soft_- 6

Andesite, dark-gray, glassy, hard-_... 45

Rock, dark-gray to black, glassy-... 5

Lava, black, scoriaceous-_. 5

Lava, black, hard

Pumice and welded tuff, tan, consolidated, layers of cinders-1. 298

Pumice, tan, consolidated, layers of welded(?)

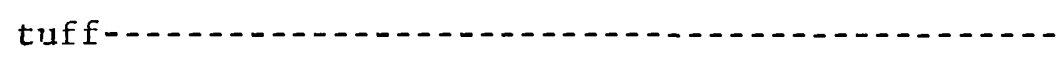


Tab1e 2.--Lithologic logs of materials penetrated in test wells--

Continued

North Entrance test wel1--Continued

\begin{tabular}{ccc}
\hline Materials & $\begin{array}{c}\text { Thickness } \\
\text { (feet) }\end{array}$ & $\begin{array}{c}\text { Depth } \\
\text { (feet) }\end{array}$ \\
\hline
\end{tabular}

Crystal pumice tuff, light-tan to cream; contains

layers of red scoria, glassy medium-gray lava----- $40 \quad 800$

Crystal tuff, layers of red-brown to black scori-

aceous lava; cuttings brown, iron stained-...- $50 \quad 850$

Volcanic glass, dark-gray, some layers of red-coated

dark-gray scoria; iron oxide stain and coating give cuttings dark red-brown color; some magnetite----- $80 \quad 930$

Lava, inflated, glassy, dark-gray to black, red iron

coating; contains much magnetite-15 15

Lava, dark-gray to dark red-brown, scoriaceous at

top; contains magnetite-1 37

Lava, medium- to dark-gray, fine-grained, hard;

contains dark-red iron-stained grains and glass,

magnetite-... $24 \quad 1,006$

Lava, 1ight pink-gray, fine- to medium-grained, veins

of cream to white secondary silica, iron oxide

stain on some crystals- $31 \quad 1,037$ 
Table 2.--Lithologic logs of materials penetrated in test wells--

\section{Continued}

Cleetwood Cove test well

LSurface altitude about $6,650 \mathrm{ft} \bar{T}$

\begin{tabular}{ccc}
\hline Materials & $\begin{array}{c}\text { Thickness } \\
\text { (feet) }\end{array}$ & $\begin{array}{c}\text { Depth } \\
\text { (feet) }\end{array}$ \\
\hline
\end{tabular}

Pumice, reddish-brown-10

Pumice, gray-brown to gray; contains rock particles and cinders

Cinders, gray-brown, glassy-... 50

Pumice, gray-brown, and cinders-... 45

Pumice, pink, massive (crystal tuff)

Rock, reddish-gray-10

Pumice, cinders, and rock particles, reddish-brown, gray, and black-170

Obsidian, black-190

Obsidian, black, and red-gray dacite cinders-_-_-- $15 \quad 205$

Dacite, reddish-gray, some pumice-10

Dacite, reddish-gray- 220

Dacite-andesite, some obsidian (medium-hard gray rock and black volcanic glass)

Andesite, dark-gray, fine-grained, hard, cavity or crevices at $255,332-334,364$, and $384 \mathrm{ft} \ldots \ldots \ldots$

Andesite, dark-gray, fine-grained, rich in magnetite, very hard 
Many seeps and springs issue from glacial moraines and till. Wherever the permeable glacial material occurs, seepage is copious from the canyon walls above the streams and from marshy ground on the canyon floors adjacent to the streams. This seepage probably results from overflow of perched ground-water bodies. These areas of glacial deposits can also be considered as being among the better locations at which to obtain water from wells, as discussed in the section on "Potential at selected areas."

Flow measurements of 106 streams and springs were made during this investigation, the results of which are listed in table 3 . The 1ocations where flow measurements were made are numbered consecutively, as shown on figure 2. Measuring site 1 is the most upstream site on Annie Creek, and subsequent sites are in a generally counterclockwise and downstream order around Crater Lake. Prior to this investigation, measurements were made at various times on Castle, Copeland, National, Sand, and Annie Creeks. Those measurements are included in Geological Survey Water-Supply Papers 574 and 1315-B.

Most of the streams and springs in the area flow throughout the year. Many of the ground-water bodies that contribute water to spring flow and streamflow appear to be recharged seasonally, as shown by the measured flow of Lightning Spring, with 0.21 cfs (cubic foot per second) in June 1968 and $0.02 \mathrm{cfs}$ in September 1968. Conversely, the flows of the larger springs, such as Thousand Springs, show little seasonal effects, as indicated by the measured flows of 32.7 cfs in June 1968 and $33.2 \mathrm{cfs}$ in September 1968. The relative uniformity of flow from the largest springs suggests that the ground-water bodies that feed them are of sufficient magnitude to mask the effects of seasonal recharge and to maintain a steady discharge throughout the year. The larger ground-water bodies probably are capable of yielding large quantities of water on a sustained basis over a long period of time.

\section{Dependable Flow}

Streams that originate under similar geologic, hydrologic, and climatic conditions can be expected to have similar flow regimens. Because Red Blanket Creek is the only stream originating in the park for which both long-term and concurrent flow records are available, its concurrent-flow measurements were compared with measurements made at six other creeks and one spring, all of which originate in the park.

Flows measured in September 1968 (as shown in fig. 3 and table 3) were at their lowest during the year, as was the flow of Red Blanket Creek. During 1968, the annual minimum daily flow of Red Blanket Creek was $44 \mathrm{cfs}$, and lower flows than this have occurred in only 4 years since 1934. Because the period covered by this investigation was the driest in many years, the low flows measured in September probably indicate the near-minimum or dependable flows that can be expected in the future. 


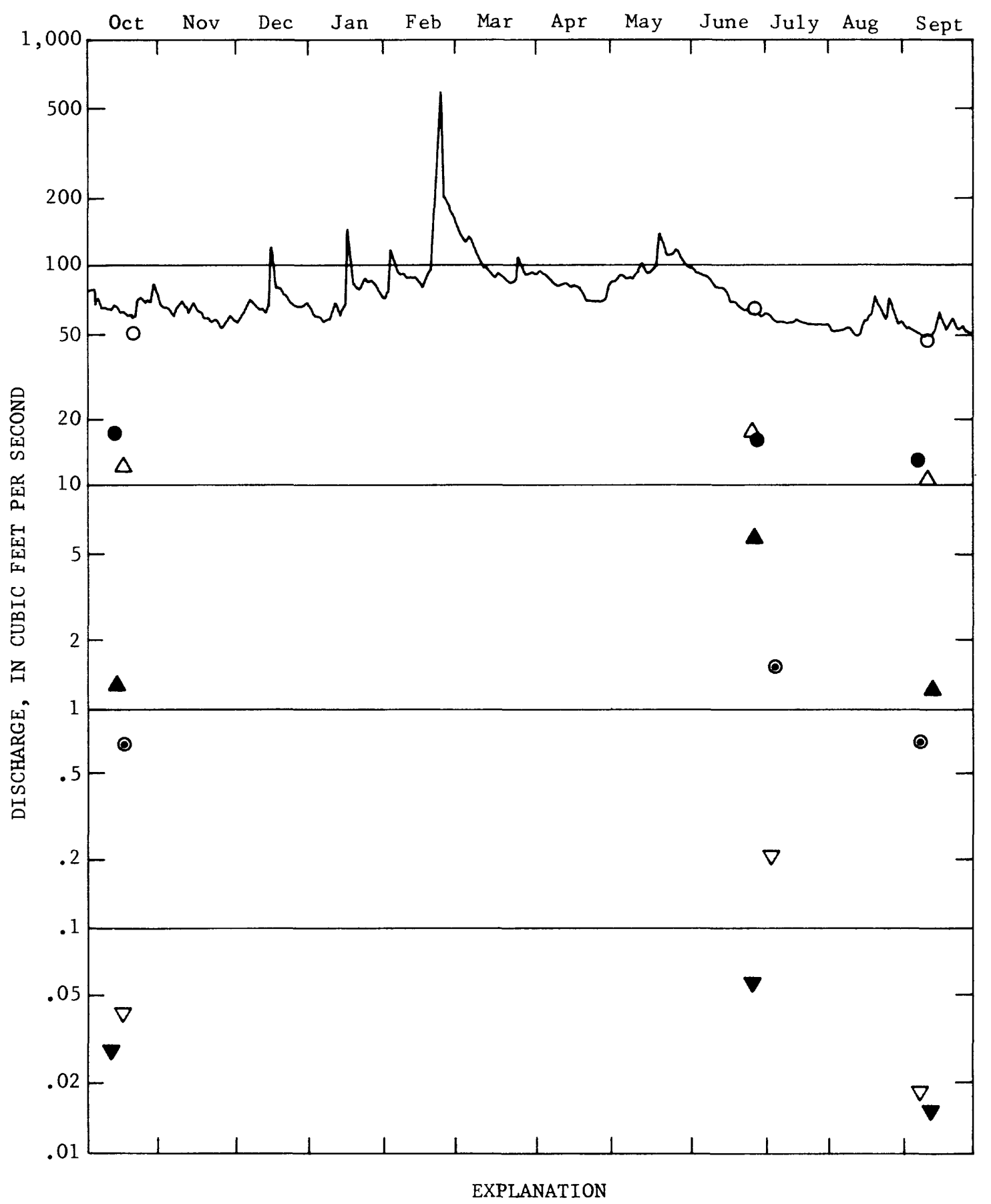

O Annie Creek at old south boundary

- Crater Creek

$\triangle$ Sun Creek near park boundary

$\Delta$ Sand Creek

- Castle Creek

$\nabla$ South Fork Copeland Creek

$\nabla$ North Junction Springs

Figure 3.--Comparison of flow of selected streams and springs with the concurrent flow of Red Blanket Creek (1968 water year). 
Table 3.--Discharge measurements of streams and springs

\begin{tabular}{|c|c|c|c|c|c|c|c|c|c|c|c|}
\hline \multirow{2}{*}{$\begin{array}{l}\text { Site } \\
\text { num- } \\
\text { ber } \\
\end{array}$} & \multirow{2}{*}{ Name } & \multicolumn{3}{|c|}{ October 1967} & \multicolumn{3}{|c|}{$\begin{array}{l}\text { June } 1968 \\
\text { (or Julyal) }\end{array}$} & \multicolumn{3}{|c|}{ September 1968} & \multirow{2}{*}{ Remarks } \\
\hline & & Day & Cfs & Gpm & Day & $\mathrm{Cfs}$ & $\mathrm{G}_{\mathrm{pm}}$ & Day & Cfs & $\mathrm{Gpm}$ & \\
\hline 1 & Annie Spring & 11 & 1.93 & $\cdots$ & 26 & 4.28 & -- & 13 & 1.48 & -- & \\
\hline 2 & Goodbye Creek & -- & -- & - & $\underline{a} / 2$ & .70 & 314 & 12 & .16 & 72 & \\
\hline 3 & Munson Springs at head & 11 & .11 & 50 & $\begin{array}{l}\text { (Too } \\
\text { here. } \\
\text { below) }\end{array}$ & $\begin{array}{l}\text { high to me } \\
\text { See no. }\end{array}$ & $\begin{array}{l}\text { leasure } \\
4\end{array}$ & $\$ 2$ & .10 & 45 & $\begin{array}{l}\text { In head box of National Park } \\
\text { Service system. }\end{array}$ \\
\hline 4 & Munson Springs & -- & -- & -- & 27 & .37 & 165 & 12 & .14 & 64 & $\begin{array}{l}\text { In natural channel } 50 \mathrm{ft} \text { below } \\
\text { head box. }\end{array}$ \\
\hline 5 & Headquarters Spring & 18 & .16 & 72 & 26 & .12 & 54 & 9 & .16 & 72 & Near superintendent's residence. \\
\hline 6 & Munson Creek & 19 & .09 & 40 & 29 & .40 & 180 & 10 & .10 & 45 & \\
\hline 7 & $\begin{array}{l}\text { Unnamed spring, Munson } \\
\text { Creek tributary }\end{array}$ & 18 & .97 & 435 & 27 & 2.08 & -- & 11 & .89 & -- & At south rim highway. \\
\hline 8 & do. & 18 & .25 & 112 & 27 & .33 & 148 & 12 & .26 & 117 & Do. \\
\hline 9 & do. & 18 & .06 & 27 & 27 & .09 & 40 & 10 & .06 & 25 & Do. \\
\hline 10 & do. & 18 & .03 & 13 & 27 & .03 & 15 & 10 & .03 & 12 & Do, \\
\hline 11 & Munson Creek & 12 & 4.80 & -- & 26 & 9.58 & -- & 11 & 3.80 & -- & \\
\hline 12 & Munson Creek tributary & 19 & -- & $<1$ & $\underline{a} / 2$ & .07 & 30 & 12 & .01 & 2.2 & $\begin{array}{l}\text { Along highway } 2 \text { miles south of } \\
\text { park headquarters. }\end{array}$ \\
\hline 13 & do. & -- & -- & -- & $\underline{a} / 2$ & .05 & 22 & 12 & .01 & 2.4 & Do. \\
\hline 14 & Pole Bridge Creek & 19 & 2.19 & -- & 26 & 2.95 & -- & 13 & 1.98 & -- & \\
\hline 15 & Cold Spring & 19 & -- & 2.9 & 26 & .03 & 14 & 13 & -- & 2.4 & \\
\hline 16 & $\begin{array}{l}\text { Middle Fork Annie Creek } \\
\text { tributary }\end{array}$ & 18 & -- & 0 & $\underline{a} / 2$ & .03 & 12 & 12 & -- & 0 & At south rim highway. \\
\hline 17 & Middle Fork Annie Creek & 18 & -- & 0 & $\underline{a} / 2$ & -- & 20 & 12 & -- & $<1$ & Do. \\
\hline 18 & $\begin{array}{l}\text { Middle Fork Annie Creek } \\
\text { tributary }\end{array}$ & 18 & - & 0 & a/ 2 & -- & 1.0 & 12 & 0 & - & Do. \\
\hline 19 & Annie Creek & -- & -- & -- & - & -- & -- & 13 & 26.1 & -- & Above East Fork. \\
\hline 20 & East Fork Annie Creek & 18 & -- & 0 & $\underline{a} / 2$ & .02 & 9 & 12 & -- & 0 & At south rim highway. \\
\hline 21 & $\begin{array}{l}\text { East Fork Annie Creek } \\
\text { tributary }\end{array}$ & 18 & -- & 0 & $\underline{a} / 2$ & -- & 3 & 12 & - & 0 & Do. \\
\hline 22 & East Fork Annie Creek & -- & -- & 0 & -- & $\cdots$ & -- & 13 & 12.8 & -- & $60 \mathrm{ft}$ upstream from mouth. \\
\hline 23 & Annie Creek & 19 & 48.5 & -- & 26 & 59.4 & -- & 10 & 44.2 & -- & At old south boundary. \\
\hline 24 & do. & 19 & 49.0 & - & 26 & 59.0 & - & 10 & 44.9 & -- & \\
\hline 25 & Sun Creek tributary & 18 & - & $<1$ & $\underline{\mathrm{a}} / 2$ & .07 & 30 & 14 & -- & $<1$ & \\
\hline 26 & Sun Creek & 15 & .26 & 12 & 29 & 1.02 & -- & 13 & .40 & 180 & \\
\hline 27 & Vidae Creek & 18 & .29 & 130 & 29 & 1.92 & $\cdots$ & 13 & .37 & 166 & Above Vidae Falls. \\
\hline 28 & Sun Creek & 16 & 12.5 & - & 26 & 17.0 & -- & 10 & 10.5 & - & Near south boundary. \\
\hline 29 & Maklaks Spring & 13 & -- & $<1$ & 28 & .01 & 4.5 & 9 & -- & $<1$ & \\
\hline 30 & Anderson Spring & 15 & 1.18 & -- & 25 & 5.72 & -- & 11 & 1.33 & $\cdots$ & At head of Sand Creek. \\
\hline 31 & Sand Creek & 13 & 1.27 & -- & 25 & 5.82 & $\cdots$ & 11 & 1.20 & -- & \\
\hline 32 & Kerr Notch Spring & 18 & -- & 1.7 & 28 & .02 & 8 & 12 & -- & 2.2 & \\
\hline 33 & $\begin{array}{l}\text { Unnamed spring, south rim } \\
\text { drive }\end{array}$ & 18 & -- & 0 & $\underline{a} / 1$ & .01 & 5.8 & 14 & -- & $<1$ & \\
\hline 34 & do. & 18 & -- & 2.8 & $\underline{a} / 1$ & -- & 2.9 & 14 & - & 2.1 & \\
\hline 35 & do. & 18 & .04 & .13 & $\underline{a} / 1$ & .14 & 64 & 14 & .03 & 14 & \\
\hline
\end{tabular}

a/ Measurement made in July. 
Table 3.--Discharge measurements of streams and springs--Continued

\begin{tabular}{|c|c|c|c|c|c|c|c|c|c|c|c|}
\hline \multirow{2}{*}{$\begin{array}{l}\text { Site } \\
\text { num- } \\
\text { ber }\end{array}$} & \multirow[t]{2}{*}{ Name } & \multicolumn{3}{|c|}{ October 1967} & \multicolumn{3}{|c|}{$\begin{array}{l}\text { June } 1968 \\
\text { (or July- })\end{array}$} & \multicolumn{3}{|c|}{ September 1968} & \multirow[t]{2}{*}{ Remarks } \\
\hline & & Day & Cfs & Gpm & Day & $\mathrm{Cfs}$ & Gpm & Day & Cfs & $\mathrm{Gpm}$ & \\
\hline 36 & $\begin{array}{l}\text { Unnamed spring, south rim } \\
\text { drive }\end{array}$ & $\cdots$ & -- & -- & $\underline{a} / 1$ & 0.24 & 106 & 14 & 0.05 & 22 & \\
\hline 37 & do. & -- & - & -- & a $/ 1$ & .26 & 117 & 14 & .05 & 21 & \\
\hline 38 & do. & 18 & - & $<1$ & $\underline{\mathrm{a}} / 2$ & .02 & 9 & 14 & -- & $<1$ & \\
\hline 39 & Sand Creek & -- & -- & -- & -- & -- & - & 14 & 11.1 & -- & $\begin{array}{l}0.2 \text { mile downstream from Lost } \\
\text { Creek Campground turnoff. }\end{array}$ \\
\hline 40 & Sand Creek tributary & 13 & 0.58 & -. & 25 & 1.38 & -- & 11 & .30 & 135 & At fire road culvert. \\
\hline 41 & Lost Creek Spring & 13 & .48 & 215 & 29 & .78 & 350 & 9 & .32 & 144 & At head of Lost Creek. \\
\hline 42 & Wheeler Creek & 13 & .21 & 49 & 29 & 1.18 & -- & 9 & .09 & 42 & \\
\hline 43 & Cavern Creek tributary & 23 & .01 & 5.5 & 27 & .03 & 15 & 11 & .01 & 4.5 & Dry $250 \mathrm{ft}$ downstream. \\
\hline 44 & Cavern Creek at mouth & 15 & 1.75 & -- & 25 & 6.52 & $\cdots$ & 11 & 1.86 & -- & $\begin{array}{l}2.9 \text { miles downstream from park } \\
\text { boundary. }\end{array}$ \\
\hline 45 & Sand Creek & 15 & 24.3 & -- & 25 & 29.2 & -- & 11 & 19.0 & -- & $\begin{array}{l}1.1 \text { miles downstream from park } \\
\text { boundary. }\end{array}$ \\
\hline 46 & Scott Creek & -- & - & -- & -- & -- & -- & 11 & .07 & 32 & At park boundary. \\
\hline 47 & do. & 17 & .08 & 36 & 28 & 1.31 & $\cdots$ & 9 & .09 & 41 & $\begin{array}{l}3 / 4 \text { mile downstream from park } \\
\text { boundary. }\end{array}$ \\
\hline 48 & Scott Creek tributary & -- & - & -- & 28 & .68 & 31 & 11 & .10 & 45 & Near park boundary. \\
\hline 49 & do. & -- & - & -- & 28 & - & 3.8 & 11 & -- & 1.5 & Do. \\
\hline 50 & do. & 17 & .11 & 49 & 28 & .70 & 314 & 9 & .09 & 40 & $\begin{array}{l}0.4 \text { mile downstream from park } \\
\text { boundary at road } 3112 \text {. }\end{array}$ \\
\hline 51 & Scott Creek & -- & - & -- & - & $\cdots$ & -- & 9 & 2.75 & - & $\begin{array}{l}4.5 \text { miles downstream from park } \\
\text { boundary at road } 2992 \text {. }\end{array}$ \\
\hline 52 & Pothole Creek & 17 & .60 & 27 & 28 & .72 & 323 & 9 & .40 & 180 & $\begin{array}{l}2.0 \text { miles downstream from park } \\
\text { boundary at road } 2992 \text {. }\end{array}$ \\
\hline 53 & Cascade Spring & 13 & 1.38 & -- & 24 & 1.66 & -. & 9 & 1.18 & -- & At head below falls. \\
\hline 54 & Bear Creek & -- & -- & - & 24 & 1.22 & -. & 9 & .78 & 350 & At park boundary. \\
\hline 55 & do. & -- & -- & -- & -- & -. & -- & 9 & - & 0 & $\begin{array}{l}1.3 \text { miles downstream from park } \\
\text { boundary at road } 2992 \text {. }\end{array}$ \\
\hline 56 & Boundary Springs & 15 & 31.1 & -- & 27 & 29.1 & -- & 6 & 24.7 & -- & Head of Rogue River. \\
\hline 57 & Minnehaha Creek & - & $\ldots$ & -- & 19 & 1.24 & -- & 7 & .11 & 49 & $\begin{array}{l}1.3 \text { miles downstream from park } \\
\text { boundary at road } 2804 \text {. }\end{array}$ \\
\hline 58 & Minnehaha Creek tributary & -- & - & -- & 19 & .59 & 265 & 7 & .17 & 76 & $\begin{array}{l}0.4 \text { mile downstream from park } \\
\text { boundary. }\end{array}$ \\
\hline 59 & do. & -- & - & -- & 19 & .22 & 99 & 7 & .01 & 4 & $\begin{array}{l}\text { Within a few hundred feet of } \\
\text { park boundary. }\end{array}$ \\
\hline 60 & do. & -- & -- & -- & 19 & .15 & 67 & 7 & -- & 5.5 & Do. \\
\hline 61 & do. & $\ldots$ & - & $\ldots$ & 19 & .14 & 63 & 7 & .03 & 12 & Do. \\
\hline 62 & do. &.- & - & - & 19 & .12 & 52.5 & 7 & .03 & 11 & Do. \\
\hline 63 & do. & -- & - & -- & 19 & .66 & 296 & 7 & .13 & 58 & Do. \\
\hline 64 & do. & -- & -- & -- & 19 & .49 & 220 & 7 & .05 & 23 & Do. \\
\hline 65 & National Creek & - & - & - & 20 & 6.6 & - & 3 & 6.3 & - & Do. \\
\hline 66 & Oasis Spring & 12 & .02 & 7 & 27 & .02 & 6.7 & 6 & -- & $<1$ & \\
\hline 67 & Middle Fork National Creek & -- & - & -- & 20 & 2.82 & -- & 3 & 2.12 & -- & At park boundary. \\
\hline 68 & South Fork National Creek & -- & -- & -- & 20 & 3.12 & - & 3 & 2.55 & -- & Near park boundary. \\
\hline 69 & $\begin{array}{l}\text { South Fork National Creek } \\
\text { tributary }\end{array}$ & - & -. & -- & 20 & 2.03 & - & 3 & .80 & 359 & At road near park boundary. \\
\hline
\end{tabular}


Table 3.--Discharge measurements of streams and springs--Continued

\begin{tabular}{|c|c|c|c|c|c|c|c|c|c|c|c|}
\hline \multirow{2}{*}{$\begin{array}{l}\text { Site } \\
\text { num- } \\
\text { ber }\end{array}$} & \multirow[b]{2}{*}{ Name } & \multicolumn{3}{|c|}{ October 1967} & \multicolumn{3}{|c|}{$\begin{array}{l}\text { June } 1968 \\
\text { (or July- } 9 \text { ) }\end{array}$} & \multicolumn{3}{|c|}{ September 1968} & \multirow{2}{*}{ Remarks } \\
\hline & & Day & Cfs & $\mathrm{Gpm}$ & Day & & $G \mathrm{gm}$ & Day & $\mathrm{Cfs}$ & Gpm & \\
\hline 70 & $\begin{array}{l}\text { South Fork National Creek } \\
\text { tributary }\end{array}$ & -. & -- & -- & 20 & 0.18 & -- & 3 & 0.02 & 10 & At road near park boundary. \\
\hline 71 & Red Cone Spring & 12 & -- & $<1$ & 27 & .04 & 18 & 6 & - & $<1$ & \\
\hline 72 & North Junction Spring & 11 & 0.03 & 13 & 24 & .06 & 26 & 10 & .03 & 12 & Inside caldera. \\
\hline 73 & Crater Springs & 12 & 16.8 & -- & 27 & 15.8 & -- & 6 & 12.5 & - & At head below forks. \\
\hline 74 & Crater Creek tributary & -- & -- & -- & 21 & 5.64 & -- & 4 & 3.70 & -- & At park boundary. \\
\hline 75 & Crater Creek & -- & - & -- & 20 & 31.8 & -- & 3 & 27.8 & - & $\begin{array}{l}0.3 \text { mile downstream from plot } \\
\text { on map. }\end{array}$ \\
\hline 76 & South Fork Copeland Creek & 14 & .04 & 19 & $\underline{a} / 2$ & .21 & 96 & 6 & .02 & 8.5 & At fire road. \\
\hline 77 & Middle Fork Copeland Creek & 14 & .03 & 13 & $\underline{a} / 2$ & .29 & 127 & 6 & .03 & 11.8 & Do. \\
\hline 78 & Copeland Creek & -- & - & -- & 21 & 12.4 & -- & 4 & 10.5 & -- & Near park boundary. \\
\hline 79 & Little Copeland Creek & -- & -- & -- & 21 & 3.67 & -- & 4 & 2.85 & -- & Do. \\
\hline 80 & $\begin{array}{l}\text { North Fork Little Cope- } \\
\text { land Creek }\end{array}$ & -- & - & -- & 21 & 1.39 & -- & 4 & 1.41 & -- & Do. \\
\hline 81 & Lightning Spring & 12 & .03 & 12 & 24 & .21 & 94 & 10 & .02 & 9 & Below pond. \\
\hline 82 & Bybee Creek & 14 & .42 & 188 & $\underline{\mathrm{a}} / 2$ & 1.54 & -- & 6 & .35 & 157 & At fire road. \\
\hline 83 & Bybee Creek tributary & 14 & .60 & 269 & $\underline{a} / 2$ & 2.21 & -- & 6 & .56 & 251 & Do. \\
\hline 84 & do. & 14 & .18 & 81 & $\underline{a} / 2$ & .23 & 108 & 6 & .12 & 54 & Do. \\
\hline 85 & do. & 14 & - & 0 & $\underline{a} / 2$ & 1.48 & -- & 6 & -- & 0 & Do. \\
\hline 86 & Bybee Creek & -- & - & -- & 22 & 19.6 & $-\cdot$ & 5 & 16.1 & -- & Near park boundary. \\
\hline 87 & Dutton Creek & 14 & .26 & 117 & $\underline{\mathrm{a}} / 2$ & 1.05 & -- & 6 & .35 & 157 & Do. \\
\hline 88 & Castle Creek tributary & 14 & .69 & -- & $\underline{a} / 2$ & 1.54 & -- & 6 & .67 & 301 & Do. \\
\hline 89 & do. & 14 & - & 2.7 & $\underline{a} / 2$ & .07 & 29.5 & 6 & - & 0 & Do. \\
\hline 90 & Trapper Creek & 14 & .09 & 40 & $\underline{a} / 2$ & .48 & 215 & 6 & .08 & 34.5 & Do. \\
\hline 91 & Trapper Creek tributary & 14 & .48 & -- & $\underline{a} / 2$ & .38 & -- & 6 & .36 & -- & Do. \\
\hline 92 & do. & 14 & .30 & -- & a/ 2 & 1.02 & -- & 6 & .35 & -- & Do. \\
\hline 93 & Whitehorse Creek & 16 & .01 & 5.7 & $\underline{a} / 2$ & .14 & 63.9 & 5 & .01 & 4.3 & At highway. \\
\hline 94 & Castle Creek & -- & -- & -- & 25 & 16.7 & -- & 5 & 11 & -- & $500 \mathrm{ft}$ above Little Castle Creek. \\
\hline 95 & Little Castle Creek & -- & -- & -- & 25 & $<.05$ & -- & 5 & $<.05$ & -- & $\begin{array}{l}\text { At mouth; dry about } 400 \mathrm{ft} \\
\text { upstream. }\end{array}$ \\
\hline 96 & Castle Creek & -. & - & -- & 22 & 19.3 & -- & 5 & 11.8 & -- & Below west boundary. \\
\hline 97 & Castle Creek tributary & -- & -- & -- & 22 & 2.70 & -- & 5 & 1.73 & - & \\
\hline 98 & Whiskey Creek & 16 & .32 & -- & 19 & .36 & -- & 2 & .28 & 126 & $\begin{array}{l}\text { At picnic ground } 1 \text { mile downstream } \\
\text { from point plotted on map. }\end{array}$ \\
\hline 99 & Union Peak Spring & - & -- & -- & -. & -- & -- & 12 & .01 & $6 . \dot{4}$ & $8 \mathrm{ft}$ below forks. \\
\hline 100 & Unnamed creek & 16 & .08 & 36 & 24 & .22 & 100 & 5 & .07 & 30 & At intake along fire road. \\
\hline 101 & Thousand Springs & 16 & 38.7 & - & 19 & 32.7 & -. & 2 & 33.2 & -- & $\begin{array}{l}\text { At road } 1 / 4 \text { mile downstream from } \\
\text { point plotted on map. }\end{array}$ \\
\hline 102 & Unnamed springs & - & -- & -- & 29 & .08 & 35 & 12 & - & $<1$ & $\begin{array}{l}\text { Should get much more flow by devel- } \\
\text { oping spring. }\end{array}$ \\
\hline 103 & Red Blanket Creek & 17 & .15 & 67 & 29 & .29 & 130 & 13 & .13 & 58 & Above park boundary. \\
\hline 104 & do. & 17 & .44 & 197 & 29 & 1.28 & - & 13 & .31 & 138 & At park boundary. \\
\hline 105 & Cedar Springs & 11 & .01 & 4.5 & 26 & .01 & 4.9 & 10 & -- & 1.5 & At head. \\
\hline 106 & do. & 11 & .01 & 4.5 & 26 & .01 & 4.9 & 12 & $\cdots$ & $<1$ & $\begin{array}{l}\text { At west branch. Should obtain much } \\
\text { more flow by developing spring. }\end{array}$ \\
\hline
\end{tabular}

a/ Measurement made in July. 
To appraise the chemical quality of the water in the area, 45 water samples were collected from streams and springs and analyzed by the Geological Survey. Eight of the samples were analyzed for all the major constituents usually included in a complete water analysis, and partial laboratory analysis was made for 37 samples. The results of the analyses are presented in table 4.

The water in the Crater Lake National Park is of excellent quality for all uses. It is very soft, has a low mineral content, and contains insignificant concentrations of objectionable constituents except, locally, iron. The general similarity in chemical composition between stream water leaving the area and the ground water from springs is apparent from the analyses in table 4.

\section{UTILIZATION AND DEVELOPMENT OF WATER}

\section{Existing Supplies}

The water supply for park facilities at present (1968) is from five springs. Park headquarters and Crater Lake Lodge use water from Munson Spring, about six-tenths of a mile north of the headquarters at altitude 7,100 feet. Water from the spring is collected in a 24,000gallon reservoir, is pumped intermittently at $50 \mathrm{gpm}$ to a $180,000-\mathrm{gallon}$ reservoir that supplies the lodge, and is allowed to flow by gravity to another 180,000 -gallon reservoir that supplies park headquarters. Total measured flow of Munson Spring was $50 \mathrm{gpm}$ in October 1967, $165 \mathrm{gpm}$ in June 1968, and $64 \mathrm{gpm}$ in September 1968. (See table 3.)

Mazama and Annie Spring Campgrounds are supplied by Annie Spring, north of the junction of State Highways 62 and 209 at altitude 6,100 feet. Discharge measurements of Annie Spring made during this investigation showed a flow of $1.93 \mathrm{cfs}$ in October $1967,4.28 \mathrm{cfs}$ in June 1968, and $1.48 \mathrm{cfs}$ in September 1968 .

Lost Creek Campground is supplied by gravity from Lost Creek Spring, which is about half a mile north of the campground. Measured flow of Lost Creek Spring ranged from about $140 \mathrm{gpm}$ in September 1968 to about $350 \mathrm{gpm}$ in June 1968.

The residence of the summer guard at The Watchman peak is supplied with water from Lightning Spring. Water from the spring is pumped to a storage tank and flows by gravity to supply the residence.

Kerr Notch viewpoint is supplied drinking water from a small spring that yields about $5 \mathrm{gpm}$. The locations of Munson, Annie, Lost Creek, and Lightning Springs are shown in figure 2 . 


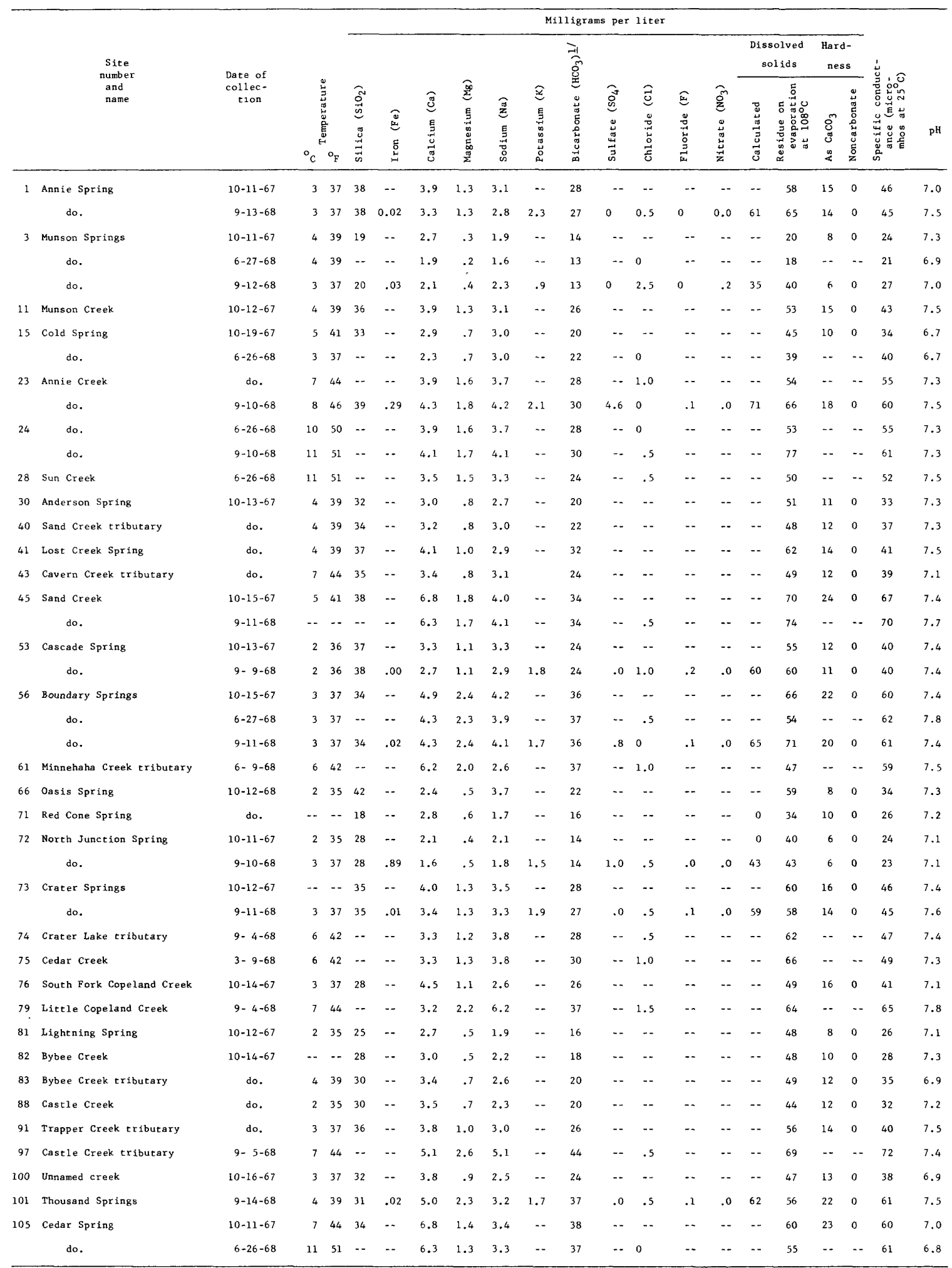

1/ Carbonate concentration in all samples was zero. 


\section{Potential at Selected Areas}

Streams, springs, and ground-water conditions in and near Crater Lake National Park were investigated to determine potential sources of water supply for park facilities. It is apparent that the construction of campsites and other recreational building should be confined to areas where water supplies are readily available.

In the western, southern, and southeastern parts of the park many springs and streams at altitudes below 6,500 feet discharge vast quantities of water. Therefore these areas are the most favorable for development of either ground or surface water. Although it is impossible to predict with certainty where and at what depths perched-water bodies can be found, it is reasonable to assume that hydrologic conditions would be more favorable for the drilling of wells in parts of the park that have the best surface-drainage system and where springs occur at various altitudes. It would be preferable to select drilling sites at lower altitudes where, if perched-water bodies are not found, wells could be more readily drilled to the regional water table.

Special emphasis was placed on selected areas discussed below.

\section{West Entrance}

Castle Creek, with a dependable flow of almost 12 cfs at site 97 , is the closest source of water for the West Entrance area (area A). However, at the park boundary, water would have to be lifted about 200 feet. Small quantities of sand or sediment in the stream could be easily removed by settling and filtration. The small unnamed creek south of Castle Point (site 100) has a dependable flow of $30 \mathrm{gpm}$, but a 3 -mile pipeline would be needed to carry the water by gravity to the West Entrance.

Thousand Springs affords the best water supply in the immediate vicinity of the West Entrance. Thousand Springs consists of a group of springs in a U-shaped valley. The series of springs starts at about the park boundary and forms a stream that is tributary to Union Creek. The springs flow from the creek banks which are covered with pumiceous and tuffaceous volcanic deposits. Although the true source of water from these springs cannot be observed, the springs probably issue chiefly from the permeable pumice which overlies dense lava rocks. Discharge measurements of Thousand Springs at site 101 ranged from 32.7 cfs in June 1968 to $33.2 \mathrm{cfs}$ in September 1968. The measurements indicate a dependable flow with small seasonal variation and a water supply adequate to support park facilities or a recreation site with a large water requirement.

The flow of Castle Creek within the park boundary is maintained mostly by spring-fed tributaries which are 4-5 miles east of the West Entrance at about 6,000 feet altitude. With few exceptions, the canyon walls along and above the creekbed are dry, which indicates that the area adjacent to and above the creekbed may be devoid of perched groundwater bodies. About a mile upstream from the West Entrance, Castle 
Creek has cut down to dense lava bedrock which is exposed in the floor of the creek. The ground-water potential is considered to be low, and wells may have to be drilled to undetermined depths below the level of the creek to tap more permeable lava beds that may contain perched water.

\section{North Entrance}

There are no springs or flowing streams in the immediate area of North Entrance (area B). The lack of surface channels in the area shows the excellent capacity of the pumice to accept precipitation; however, the results of test drilling ( $p$. ) indicate that perched-water bodies apparently are few. In this part of the park, artificial catchment aprons and storage cisterns could be constructed to provide water to points of use. Artificial collection and storage facilities could be developed for small installations in any part of the park where streams and springs are not available.

Water to support large facilities can be obtained from Boundary Springs in the northwest corner of the park about 5 miles west of the North Entrance. The total measured flow of these springs was $24.7 \mathrm{cfs}$ in September 1968. Water from these springs could be pumped to storage facilities at higher altitudes and then transferred by gravity flow to points of use in the northern and northwestern parts of the park. The geologic and hydrologic features of the springs are typical of springs in the park area. High above the springs the land surface is composed of pumice which accepts precipitation and transmits water to the springs. The springs issue from the base of the pumice where it rests on dense lava. Figure 4 shows the water forming a falls as it courses over the lava.

\section{old South Boundary}

Potential water-supply sources for old south boundary (area C) are Annie Creek, we11s, and Pole Bridge Creek. Dependable flow of Annie Creek (site 23) is about $44 \mathrm{cfs--many} \mathrm{times} \mathrm{the} \mathrm{30,000} \mathrm{gpd} \mathrm{(gallons} \mathrm{per}$ day) needed for planned facilities. The creek flows in a narrow canyon about 300 feet deep, so that creek water would have to be lifted a few hundred feet if the creek were developed for use.

The canyon of Annie Creek is cut deeply into pumice fill below which may lie glacial materials or lava bedrock. The flow of Annie Creek increases about 5 cfs from the mouth of East Fork Annie Creek to the old south boundary (site 23, table 3). This indicates that perchedwater bodies may contribute to the flow along this reach of the stream. Because these perched-water bodies probably occur at altitudes near stream level, it may be possible to obtain water supplies by drilling wells to or slightly below the level of Annie Creek. 


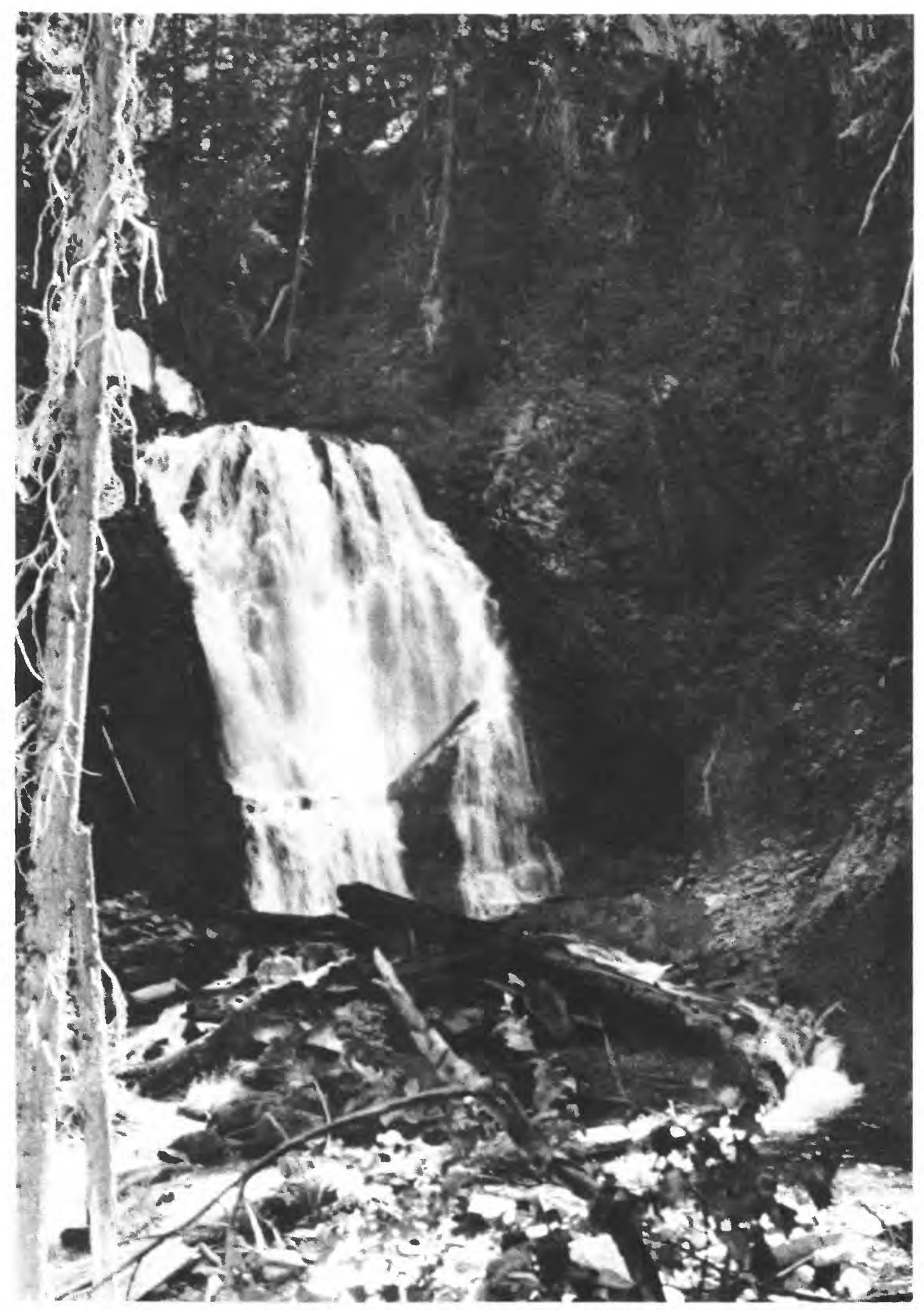

Figure 4.--Boundary Springs falls, about 100 feet below point at which flow measurements were made. 
If a well drilled in this part of the area obtained no water from perched zones at or near stream level, it would be necessary to drill to and below the regional water table to obtain adequate water supplies for camp facilities. The regional water table may be at about the same altitude as in the south utility area--4,400-4,500 feet. Because the volcanic-rock section contains many non-water-bearing lava units, a we11 may have to be drilled to a depth of 900-1,000 feet to penetrate rocks permeable enough to yield the volume of water needed.

A third alternative source would be to obtain water by gravity flow through a pipeline from Pole Bridge Creek. That creek has a dependable flow of about 2 cfs (more than 1 million gallons per day) at site 14 , about 5 miles north of the old south boundary area.

\section{South Utility}

Water in the south utility area (area D) can be obtained from wells or by gravity flow from Cedar Spring, about 2 miles northwest of the South Entrance.

The surface near the South Entrance is composed of pumiceous materials and other volcanic debris. At the park boundary, the altitude of Annie Creek is about 4,500 feet, and the creek flows out to the Fort Klamath Plain. There, the regional water table may be at 4,300-4,400 feet (Newcomb and Hart, 1968, p1. 2B). Several private wells near the South Entrance obtain water from shallow wells dug in the alluvium near Annie Creek. In the south utility area, wells of shallow depth might yield adequate-supplies of water; however, it is possible that wells may have to be drilled several hundred feet to reach permeable pumice or lava bedrock capable of yielding water in quantities sufficient for planned park facilities. Because the exact nature, permeability, and water-transmitting capabilities of the underlying material are unknown, it should be anticipated that a well may have to be drilled to a depth of about 600 , feet to obtain adequate water supplies.

Cedar Spring consists of a series of seeps with several small discharge outlets. The surrounding area is overlain by pumiceous material, from which the flow of the spring emanates. The measured flow of this spring (from two branches, sites 105 and 106) was about $9 \mathrm{gpm}$ in June 1968 and about $2.5 \mathrm{gpm}$ in September 1968. If this spring could be developed to collect all seepage and to channel all the water into a single facility, it might produce more water than the measured September flow.

The south utility area is one of the more favorable areas within the park in which to drill wells. Because Cedar Spring is capable of producing only small quantities of water, ground water from wells probably is the best potential source of water for this part of the park. 


\section{North Junction}

Water needed (about 1,000 gpd) for a rest stop or comfort station at the North Junction (area E) can be obtained from a spring below the northwest rim of the caldera about a thousand feet above the lake. The surface above the spring is composed of permeable pumiceous materials that allow the infiltration of precipitation and act as reservoir materials for the storage of water. Water seeps through the permeable surface materials and issues at their contact with the more dense underlying rocks to form a spring. Flow measurements of the spring (site 72) indicate a dependable flow of $12 \mathrm{gpm}$, adequate to supply the needs of the planned facility.

\section{Munson Valley}

Munson Valley (area F) is a U-shaped glaciated valley, and because of its geologic and physiographic characteristics it is one of the more promising areas in the park for the development of water supplies. Throughout much of the valley, surficial deposits of pumice overlie hummocky morainal material. Proof of this is seen in the walls of the Middle Fork of Annie Creek, where the upper and drier slopes of pumice extend down into wet banks of bouldery till. Seepage from the lower part of the canyon walls indicates the drainage of perched ground water. It is possible that ground water could be obtained from perched zones that may occur in the permeable underlying glacial materials, particularly in the south end of the valley along Annie Creek and its middle fork.

At the north end of the valley southeast of park headquarters, several springs that flow from permeable pumice and bouldery glacial drift form tributaries to Munson Creek (sites 7-10, table 3). In September 1968 the springs had a combined flow of about $1.5 \mathrm{cfs}$, which would be adequate water for the needs of a fairly extensive park development. The springs are close to one another, and the flow of two or more of the springs could be diverted into a single water-supply facility. Additional water supplies for this part of the park can be obtained from Headquarters Spring (site 5) and Munson Creek (site 6). In September 1968, the measured flow of Headquarters Spring was $72 \mathrm{gpm}$ and the measured flow of Munson Creek was $45 \mathrm{gpm}$.

\section{Potential at Other Areas}

Cascade Spring (site 53, fig. 2) is the source of Bear Creek and is the only potential water supply of any consequence in the extreme eastern part of the park. The spring issues from the base of a bouldery moraine resting on dense lava. Higher up the valley above the spring, hummocky glacial drift lightly covered with fine granular pumice serves as an excellent medium for the infiltration and transmittal of water. Flow measurements of the spring (table 3) show small seasonal effects and a relatively uniform flow. The quantity of water available (1.18 cfs measured in September 1968) and the general desirability of the Bear Creek area make this location suitable for a variety of park facilities. 
Crater Lake, according to K. N. Phillips (1968, p. E1), receives about 89,600 acre-feet of water annually. The 1 ake, which contains about 14 million acre-feet of water, loses about 25,200 acre-feet annua11y to evaporation and about 64,400 acre-feet to seepage 1 oss. The water contains about $80 \mathrm{mg} / 1$ (milligrams per liter) of dissolved solids-mostly silica, sodium, and bicarbonate. These data suggest that a good supply of water for facilities on the northeast rim of the lake could be obtained directly from the lake. The lake water would have to be lifted about 525 feet to deliver water to the three lowest points on the rim and about 925 feet to deliver water to the existing lodge.

\section{SUMMARY}

The principal conclusions resulting from this study are:

1. The park has ample supplies of water in the western, southern, and southeastern parts. Vast areas of the park, particularly at the north end, have no readily available supplies.

2. In most parts of the park, springs and spring-fed streams that flow throughout the year are good sources of water supply. We11s may be developed in favorable areas, particularly in parts of Munson Valley and near the South Entrance.

3. In the northern part of the park, catchment basins or storage cisterns could be constructed to collect the seasonal precipitation for use as a water supply. Such a supply could be developed for small installations at any point in the park where springs and streams are not available.

4. The water from springs and streams in Crater Lake National Park is very soft, has a low mineral content, and contains insignificant concentrations of objectionable materials except, locally, iron. Most is of excellent quality for all uses. 
Diller, J. S., and Patton, H. B., 1902, The geology and petrography of Crater Lake National Park: U.S. Geol. Survey Prof. Paper 3, $167 \mathrm{p}$.

Newcomb, R. C., and Hart, D. H., 1958, Preliminary report on the groundwater resources of the Klamath River basin, Oregon: U.S. Geol. Survey open-file rept., 248 p.

Phillips, K. N., 1968, Hydrology of Crater, East, and Davis Lakes, Oregon: U.S. Geol. Survey Water-Supply Paper 1859-E, 60 p.

Sternes, G. L., 1963, C1imate of Crater Lake Nationa1 Park: The Crater Lake Natural History Assoc., 12 p.

U.S. Geological Survey, 1927, Surface water supply of the United States, 1923. Part XII. North Pacific slope drainage basins. C. Lower Columbia River basin and Pacific slope drainage basins in Oregon: U.S. Geo1. Survey Water-Supply Paper 574, 194 p.

1960, Compilation of records of surface waters of the United States through September 1950. Part II-A. Pacific slope basins in California except Central Valley: U.S. Geol. Survey WaterSupply Paper 1315-B, 874 p.

Williams, Howel, 1942, The geology of Crater Lake National Park: Carnegie Inst. Washington Pub. 540, 162 p. 